\title{
Presentation of the Trepanned Skull Labelled MO-90, Found in the Avar Cemetery on the Territory of Settlements Ómoravica-Kopláló in Serbia
}

\author{
Presentación de Cráneo Trepanado Etiquetado MO-90, Encontrado en el Cementerio \\ de Avar en Territorio de los Asentamientos Ómoravica-Kopláló en Serbia
}

\section{Géza Czékus}

CZÉKUS, G. Presentation of the trepanned skull labelled MO-90, found in the Avar cemetery on the territory of settlements ÓmoravicaKopláló in Serbia. Int. J. Morphol., 36(1):243-247, 2018.

SUMMARY: The most prominent issues in paleopathology concerning skull lesions are skull trepanation and artificial deformation of the skull. From the very beginnings of this scientific field, these two groups of alterations have been the focus of interest. Since the second half of the 19th century, countless pathologists, surgeons and ethnologist have dealt with this issue. The interest is still great. Nevertheless, numerous questions regarding skull trepanation and artificial deformation are yet to be answered. The first trepanned skull finds were discovered in France and Hungary. The finds in Hungary are interesting because a large number of trepanned skulls were found in a relatively small area. On the skull remains found in the grave discovered in the Òmoravica-Koplaló cemetery and labelled MO-90, left of the Sutura sagittalis there is a hole about $1 \mathrm{~cm}$ in diameter. There are no pathological lesions along the edge or around the hole.

KEY WORDS: Skull; Trepanation; Ómoravica.

\section{INTRODUCTION}

Head injuries make up 6-20\% of all injuries in accidents today. Throughout human history, the skull suffered injuries far more often than the long bones (postcranium), for in fights and warfare the defenceless head used to be the main target (Józsa, 2006). Fractures of facial bones (cranium viscerale) are less frequent than those of the cranial bones (cranium cerebrale). In larger paleopathological collections, $1-5 \%$ of the skulls have suffered cranial injuries and subsequent complications as a result of falls, slamming into hard objects, or injuries by (blunt) objects (Pap \& Józsa, 1991).

The paleopathological classification of bone lesions was carried out on the basis of disease groups by Steinbock (1976) and Ortner \& Putschar (1985).

In palaeopathology, one of the best known disorders affecting the skull is trepanation. Trepanation is intentional surgery during which bone material was removed from the skull (Bereczki, 2013). Under external forces the skull broke open, the depressed part was taken out and the bone edges rubbed off.
During surgical skull trepanation, a bone fragment was removed from the skull of a living person, so that all three layers of the bone were cut through (usually drilled, scraped, rubbed, carved). This procedure was typically used to "cure" complications resulting from skull lesions involving fracture: Broken bone fragments were removed from the wound acquired in combat, the broken edges were straightened, and after healing, the bone-deficient area was covered with some kind of harder material (Bereczki). There may have been additional reasons for surgical trepanation, but they are not discussed in this paper. Whether the patient survived the operation, depended on whether the meninges and the brain were injured in the initial injury, and if an infection developed or not. In the case of symbolic trepanation, this act was generally performed in cult practices, during which process the bone was not broken through, only small round or plum-stone shaped forms were carved into the outer layer (the tabula externa). This kind of intervention could also have an etiological background.

In the Carpathian Basin, trepanation emerged with the appearance of various ethnic groups in the Migration 
Period; in the case of the Magyars, skulls with multiple trepanation openings were also found. The custom probably ended after the establishment of Christianity in this region, even though surgically trepanned skulls can also be found in 12 th century cemeteries.

During trepanation as cult practice, a piece of bone was taken out of the skull of a victim killed with one's own hands, possibly in combat, in order to make an amulet.

Today, skull trepanation is still performed in tribal societies. In Hungary, the first trepanned skull was found in Vereb in 1853, in a tomb from the Hungarian Conquest period. János Érdy reported about this case in 1858, and was one the first scientists publishing on this matter worldwide (Bereczki).

According to Józsa, historical Hungary used to be one of the centers of skull trepanation. Citing Bartucz (1966), he says that nowhere in the world are there this many findings in such a small area. In more than half of the cases, the artefacts derive from the Hungarian Conquest period and the Árpád-era.

Józsa \& Fóthi (2007) dealt in detail with trepanned skulls found in Hungary; they produced a catalogue listing all published and unpublished surgical trepanations. From this catalogue (also encompassing areas beyond the borders) we learned that $3 / 4$ of 130 trepanation cases were men. In $63 \%$ of the cases trepanning was successful and provided the patient with long time survival. The lesion is $1-18 \mathrm{~cm}$. $94 \%$ of trepanations occurred on the forehead (os frontale) and on the frontal part of the parietal bone (os parietal), in $3 / 4$ of the cases on the left side of the skull. This suggests that the trepanation was preceded by traumatic injury (assault).

Several trepanned skulls have been found in Vojvodina as well. During the exploration of an Early Bronze Age necropolis in Mokrin (Mokrin, Kikinda municipality), Farkas \& Lipták (1971) found 8 certain trepanned skulls and 3 questionable trepanned skulls. Czékus (Czékus, 1985, 1991, 1996) reports about the finds in Ómoravica-Koplaló from the Late-Avar Period; furthermore, two trepanned skulls were found in the 9-15th century cemetery in Majdan (Majdan, Törökkanizsa, N. Knezevac municipality) (Dimovski, 2013). In Omlód (Omoljica, Pancevo municipality) in the 12-13th century site called Preko Slatine, a male trepanned skull was discovered. Moreover, the female skull found in grave No. 159 on site No. 85 originating from the 13-16th century in Sremska Mitrovica, was also trepanned (Dimovski).
From the very beginnings of paleopathology, trepanation has been the focus of interest. Since the second half of the 19th century, every major pathologist, surgeon and ethnologist has dealt with this issue, and the interest is still great. Nevertheless, even today, trepanations raise a multitude of unanswered questions.

With this article we would like to extend our general understanding of trepanation finds in the Carpathian Basin.

\section{MATERIAL AND METHOD}

Vojvodina (Northern Serbia) is rich in archaeological sites. There are sites from all historical periods. The greater ones were disclosed, and the results published.

The Avar Period is also rich in artefacts. The largest cemeteries are in: Bácstopolya (today Topola, BackaTopola), Ómoravica (Bácskossuthfalva, Stara Moravica), Magyarkanizsa (Kanizsa, Kanjiza), Horgos (Horgos) and Bácsandrásszállás (Backi Sokolac). The archaeological and anthropological finds in these and a few other, smaller cemeteries are described in the publications of Szekeres (1981), Ricz (1980), Farkas \& Marcsik (1984) and Géza Czékus (1985, 1991), Cekus (1991, 1996).

In 1976, while laying the groundwork for the roadway connecting Bajmok to Ómoravica, workers discovered graves. This spot is located along the road Topolya-Bajmok, on the section Moravica-Pacsér (Pacir), one kilometer north of Ómoravica, on the fringe of the Koplaló Valley. The valley runs parallel to the Bács-ér (Krivaja) Valley, which stretches from Bajmok to BackaTopola. It is a peninsula-shaped elevation bisected by the roadway. Prior to the landscaping works for the recreation centre (from 1977) excavations were conducted, led by Péter Ricz, archaeologist of the Municipal Museum in Subotica. With minor interruptions, the work went on until 1983. The cemetery had been actively used for 100-120 years, from the second half of the 7th century until the end of the 8th century. 204 graves were excavated (the last eight graves were excavated in 1983).

Except for the children's graves, the graves are deep. Timbering can be often found on their sides and at the bottom. The tombs have the features of the Late Avar Period (jewelry, decorated bone objects, bronze belt plates, knives, pottery). The corpses are usually lying on their backs, face toward south-southeast. The graves have not been disturbed. The structure of the bones is greatly damaged due to the implosion of the massive wooden constructions. The finds are kept in the Municipal Museum in Subotica. 
Table I. The age and sex of the deceased.

\begin{tabular}{lcccccccccc}
\hline Sex & Inf & Inf. I. & Inf.II. & Juv. & Ad. & Mat. & S en. & $?$ & All & $\%$ \\
\hline$?$ & 3 & 8 & 8 & 1 & 2 & 2 & 1 & 9 & 34 & 18.4 \\
Males & & & & 1 & 4 & 51 & 23 & 2 & 81 & 43.8 \\
Females & & & & 8 & 6 & 45 & 10 & 1 & 70 & 37.8 \\
Together & 3 & 8 & 8 & 10 & 12 & 98 & 34 & 12 & 185 & 100.0 \\
$\%$ & 1.6 & 4.3 & 4.3 & 5.4 & 6.4 & 53.2 & 18.4 & 6.4 & 100.0 & 100.0 \\
\hline
\end{tabular}

Anthropological interpretation was carried out at the Municipal Museum in Subotica. After restoration and identification, we determined the assumed age and sex of the person (Acsádi-Nemeskéri, 1970), the metric and morphological features of the bones (anatomical variations) (Martin \& Saller, 1957), and processed the data. Finally, we compared our results with other contemporary finds.

Our studies covered the first 196 graves (Table I). Of these, 11 were empty. 34 skeletons are of indeterminate sex. $86.5 \%$ of the material can be measured. A total of 70 female and 81 males were identified. Most of them were of mature age (63\% of the men, $62.5 \%$ of the women). The sex indexes were +0.93 and -0.92 .

\section{CASE PRESENTATION}

Anthropological Description of Skeleton MO-90. This is an averagely-preserved skeleton of a robust man (Fig. 1). The basis cranii (basilar part of the occipital bone) and the

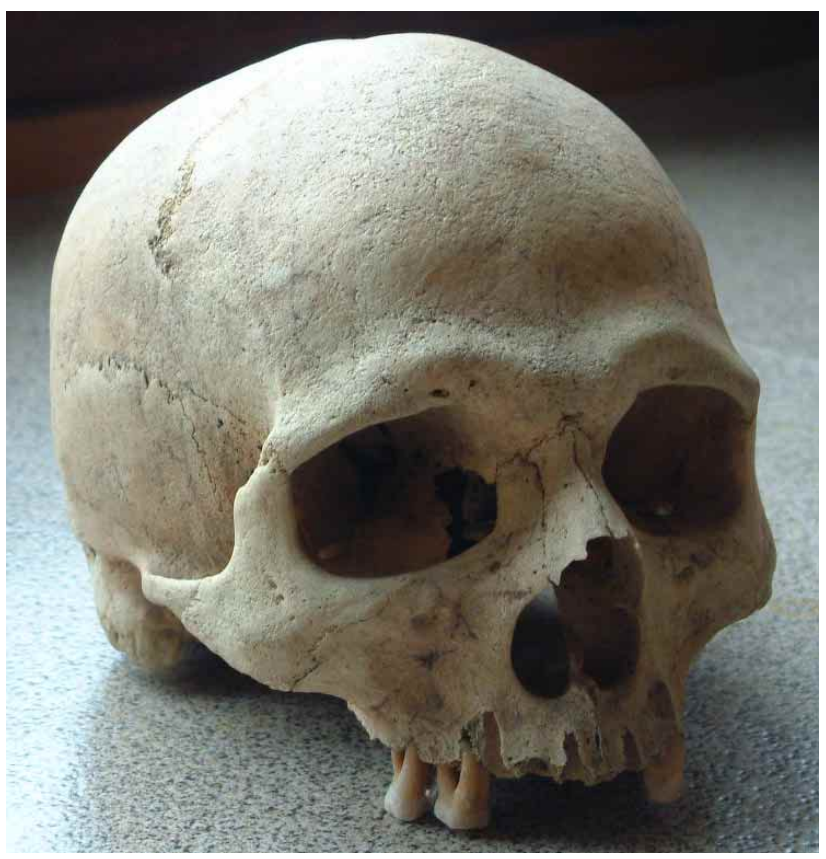

Fig. 1.The front view of skull MO-90.
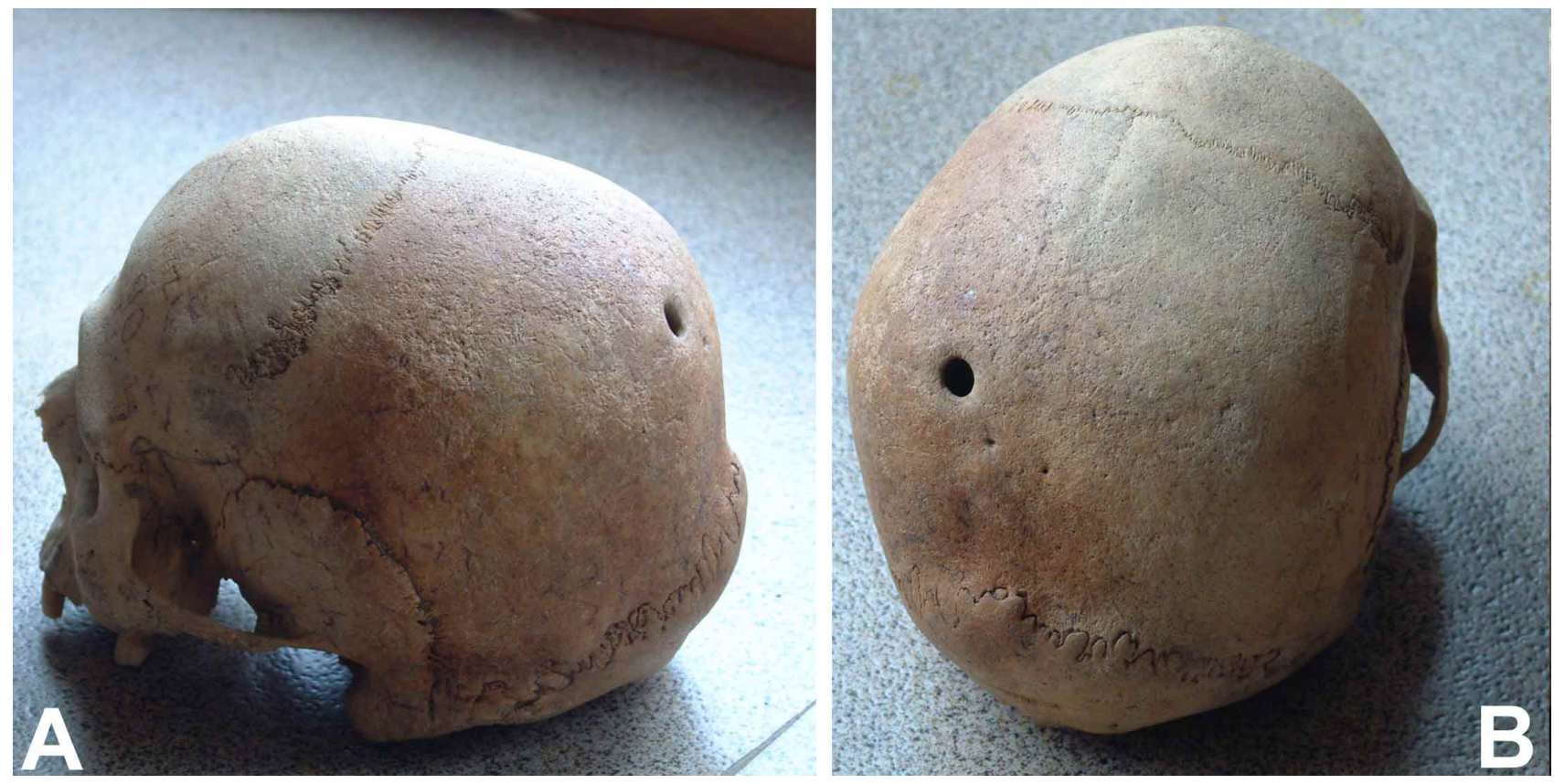

Fig. 2. The lateral and upper view of the skull. The trepanned opening is a regular circle $9.3 \mathrm{~mm}$ in diameter. 
os palatinum facing osoccipitale is missing. Otherwise, the rest of the skull, including the calvaria, is intact. The cranial sutures are almost completely closed (the sagittal suture is closed). The teeth found during the excavation are worn.

Sex. index +0.8 . Estimated age: senium (65 years). The skull is medium-long $(\mathrm{M} 1=181)$ and very narrow $(\mathrm{M} 8=135)$, long (dolichokran, $8 / 1=74.59$ ). We calculated the height from three values (the 2 humerus, and the right radius); it is $168.6 \mathrm{~cm}$.

The morphological description of the skull: symmetrical, ovoid in Norma verticalis, house-shaped in N. occipital, the glabellar is 5 , the protuberantia occipital externa is 3 , the spina nasalis anterior is 2 , the prognathia alveolaris is 3 .

The Description of the Trepanned Opening. The opening is on the left parietal bone (os parietal) (Fig. 2). It is almost circular in shape, located $17.5 \mathrm{~mm}$ from the suture sagittalis (pars obelica), that is $46 \mathrm{~mm}$ above the suture lambdoidea (pars media). The diameter of the aperture is $9.3 \mathrm{~mm}$. The skull is $4.2 \mathrm{~mm}$ thick around the trepanned part. The edge of the opening is rounded on the in- and outside, cured and regular (Fig. 3). Under 45x magnification, the diploid
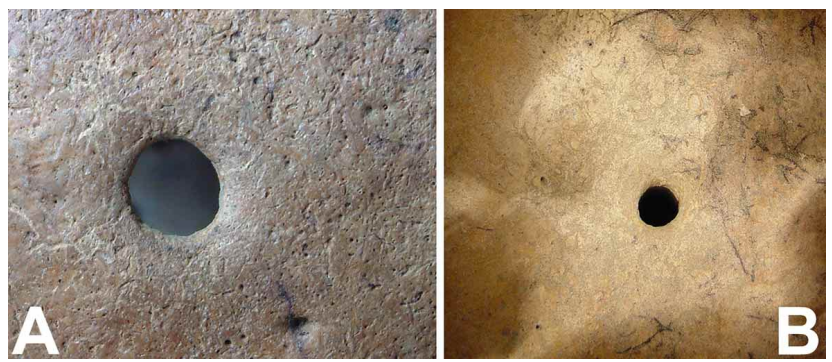

Fig. 3. The exocranial and endocranial surface of the trepanation. Both edges are rounded. chambers seem to be closed (they close completely in a maximum of six months after the procedure). The endocranial surface around the opening is slightly indented. There are no pathological lesions. The rubeanic acid procedure was not used.

Two radiographs of the skull were made (Fig. 4). One was made in anteroposterior direction, while the other one is a lateral view. According to the radiologist, there are no pathological lesions.

\section{CONCLUSION}

Trepanation, an external intervention of opening the skull, is one of the best-known skull-related issues in palaeopathology. Despite the fact that it is a complicated, life-threatening procedure, more than a half of patients survived for a long time.

Surgical skull trepanation is known on almost every continent, and is still practiced in tribal societies. There are a large number of cases, which is especially true for Hungary. Józsa and Józsa \& Fóthi estimates that there are 150. Unfortunately, many are unpublished.

In this article a find from Vojvodina was described. Successful surgery was carried out on the skull of an elderly man (labelled M-90), whose remains were found on the archaeological site Ómoravica-Koplaló.

This publication enhanced our understanding of trepanation finds in Vojvodina.
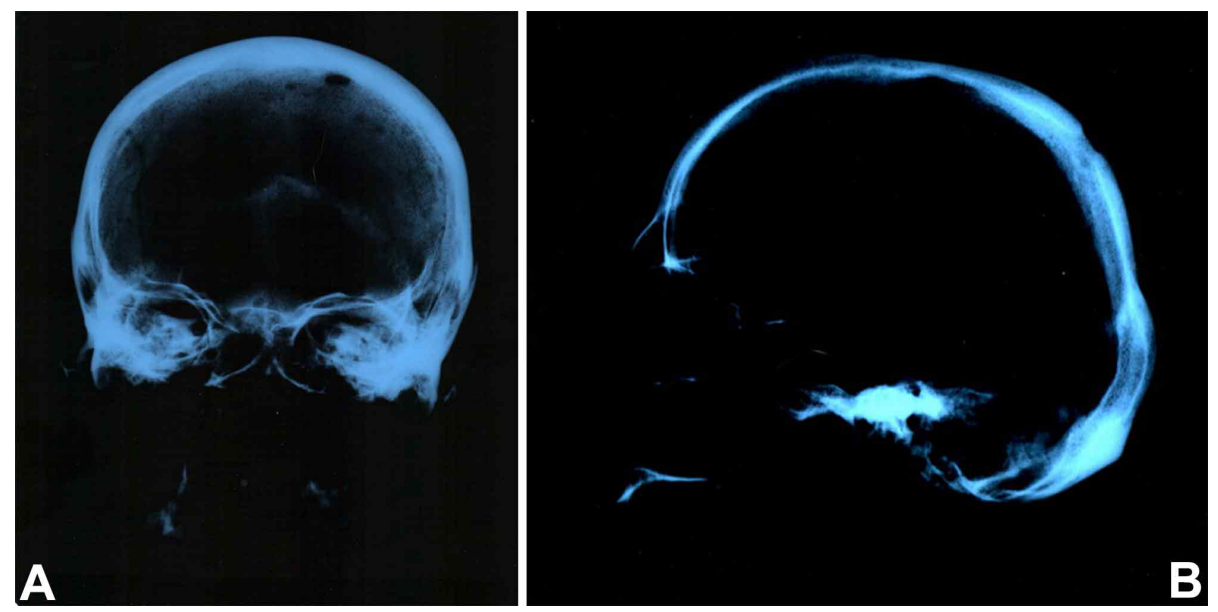

Fig. 4. N. frontal and N. lateral radiographs of MO-90 
CZÉKUS, G. Presentación de cráneo trepanado etiquetado como MO-90, encontrado en el cementerio de Avar en el territorio de los asentamientos Ómoravica-Kopláló en Serbia. Int. J. Morphol., 36(1):243-247, 2018.

RESUMEN: Los temas más destacados en la paleopatología con respecto a las lesiones del cráneo son la trepanación y la deformación artificial éste. Desde los comienzos en esta área científica, estos dos grupos de alteraciones han sido el foco de interés. Desde la segunda mitad del siglo XIX, un número importante de patólogos, cirujanos y etnologistas se han enfocado e interesado en este tema. Sin embargo, aún existen preguntas y numerosas dudas sobre la trepanación del cráneo y la deformación artificial. Los primeros hallazgos de cráneos trepanados se descubrieron en Francia y Hungría. Los hallazgos en Hungría son interesantes debido a que es un área relativamente pequeña, pero fueron encontrados una gran cantidad de cráneos trepanados. En los restos de cráneos encontrados en la tumba del cementerio Òmoravica-Koplaló y etiquetados como MO-90, a la izquierda de la sutura sagital se observó un foramen de aproximadamente $1 \mathrm{~cm}$ de diámetro. No hay lesiones patológicas a lo largo del margen, tampoco alrededor del foramen.

PALABRAS ClAVE: Cráneo; Trepanación; Ómoravica.

\section{REFERENCES}

Bereczki, Z. The Trephining Traditions of the Avars as Reflected in the Bioarcheological Material of the Southern Great Plain. Ph.D. Thesis. Szeged, University of Szeged, 2013.

Czékus, G. Anthropological study of the Avars necropolis in Stara Moravica. Rad Vojv. Muz., 33:85-106, 1991.

Czékus, G. Anthropological Study of Three Avars Necropolises in Severn Backa. Ph.D. Dissertation. Novi Sad, University of Novi Sad, 1991.

Czékus, G. The Human Character of the Skeletal Remains of the Avar Cemetery in Moravica (Stara Moravica). Ph.D. Dissertation. JATE, Szeged, 1985.

Czékus, G. Trepanation. Glasnik ADJ, 32:5-8, 1996.

Dimovski, N. Medieval Blessings in Vojvodina. Ex Pannonia, 17:1057, 2013.

Farkas, G. \& Lipták, P. Physical Anthropological Examination of a Cemetery in Mokrin from the Early Bronze Age. In: Giric, M. (Ed.). Mokrin - The Early Bronze Age necropolis. Washington-KikindaBelgrad, Dissertationes et Monographie XI, 1971. pp.239-71.

Farkas, G. \& Marcsik, A. Avar poeriod anthropologic findins from Backa Topola site (Yugoslavia) (Publication of data). Acta Biol. Szeged., 30:191-205, 1984.

Józsa, L. \& Fóthi, E. Treated skulls in the Carpathian Basin. Folia Anthropol., 6:5-18, 2006.

Józsa, L. Paleopathologia. The Diseases of our Ancestors. Budapest, Semmelweis Publisher, 2006.

Martin, R. \& Saller, K. Lehrbuch der Antropologie Bd I-II G. Stuttgart, Fisher Verlag, 1957.

Ortner, D. J. \& Putschar, W. G. J. Identification of Pathological Conditions in Human Skeletal Remains. Washington, Smithsonian Institute, 1985.

Pap, I. \& Józsa, L. The frequency, care and healing of skull injuries. Honvédorvos, 32:83-92, 1991.
Ricz, P. Koplalo - recreation center, St. Moravica - an avant-garde necropolis. Archaeol. Surv., 21:166, 1980.

Steinbock, T. R. Paleopathological Diagnosis and Interpretation: Bone Diseases in Ancient Human Populations. Springfield, Charles C. Thomas, 1976.

Szekeres, L. What Time Buried. Forum Series of Small Libraries. Forum, Novi Sad, 1981.

\author{
Corresponding Author: \\ Dr. Czékus Géza \\ Uiversity of Novi Sad \\ Hungarian Language Teacher Training Faculty \\ Subotica \\ SERBIA
}

Email: czekus.geza@gmail.com

Received: 22-06-2017

Accepted: 13-10-2017 